\title{
GENDER CHARACTERISTICS OF PRIMARY SCHOOL STUDENTS' SUCCESS IN SOLVING TASKS IN THE CONTEXT OF VARYING EXTRINSIC MOTIVATIONAL ATTITUDES
}

\author{
CARACTERÍSTICAS DE GÊNERO DO SUCESSO DOS ALUNOS DO ENSINO \\ FUNDAMENTAL NA RESOLUÇÃO DE TAREFAS NO CONTEXTO DE DIFERENTES \\ ATITUDES MOTIVACIONAIS EXTRÍNSECAS
}

\author{
CARACTERÍSTICAS DE GÉNERO DEL ÉXITO DE LOS ESTUDIANTES DE \\ PRIMARIA EN LA RESOLUCIÓN DE TAREAS EN EL CONTEXTO DE VARIANTES \\ ACTITUDES EXTRÍNSECAS DE MOTIVACIÓN
}

\author{
Alexandr SAVENKOV ${ }^{1}$ \\ Olga GAVRILOVA ${ }^{2}$
}

\begin{abstract}
The article presents the results of an empirical study of specific characteristics of the success of boys and girls of primary school age in solving convergent problems under the condition of varying motivational attitudes. The study was conducted in the elementary school of the State Budgetary Educational Institution of Moscow "School No. 1561" educational complex in 2016-2018. The study sample includes 239 second-grade students, the average age of whom was 8.2 years old. 137 of the study participants were boys and 102 were girls, which constitutes $57 \%$ and $43 \%$ of the sample, respectively. Motivation is assessed via the authors' modification of N. V. Elfimova's method "A ladder of motives", a version of M. Seligman's Children's Attributional Style Questionnaire (CASQ) modified by N. A. Baturina and D. A. Tsiring, and the authors' modification of C. Dweck's Implicit Theory Scale. The study of the cognitive sphere of the primary school students involves J. Raven's progressive matrices test, P. Torrance's test of creative thinking, and E. E. Tunik's adaptation of J. Johnson's creativity scale. Within the framework of the experiment, two blocks of convergent tasks are formed: one including non-verbal transitivity tasks (the logical block) and the other containing volumetric and spatial thinking tasks (the spatial block). It is established that the success of primary school students of both sexes in solving convergent tasks is associated not only with the extrinsic motivational attitude, constructed through verbal instruction, but also with the specific psychological characteristics of the development of the cognitive and motivational spheres in children. The relationship between the success in solving convergent tasks and the psychological characteristics of cognitive development and the motivational sphere differs for boys and girls of primary school age, which manifests most intensely in the level of development of the non-verbal component, the leading motivation, and the specifics of the development of the attributional style of explaining success and failure, as well as its components.
\end{abstract}

KEYWORDS: Motivation. Gender. Convergent tasks. Success. Students.

1 Moscow City University (MCU), Moscow - Russia. Dr. Professor and Corresponding Member of RAO. ORCID: https://orcid.org/0000-0001-7532-7540.E-mail: asavenkov@bk.ru

${ }^{2}$ Moscow Pedagogical State University (MPGU), Moscow - Russian. Senior Lecturer. PhD in Psychology. ORCID: https://orcid.org/0000-0003-0777-0246. E-mail: oya.gavrilova@mpgu.edu 
RESUMO: $O$ artigo apresenta os resultados de um estudo empírico das características específicas do sucesso de meninos e meninas do ensino fundamental na resolução de problemas convergentes sob a condição de atitudes motivacionais variadas. $O$ estudo foi realizado na escola elementar do Instituto Estadual de Educação Orçamentária de Moscou do complexo educacional "Escola No. 1561" em 2016-2018. A amostra do estudo inclui 239 alunos da segunda série, cuja média de idade era de 8,2 anos. 137 dos participantes do estudo eram meninos e 102 eram meninas, o que constitui 57\% e 43\% da amostra, respectivamente. A motivação é avaliada através da modificação dos autores do método "Uma escada de motivos" de N. V. Elfimova, uma versão do Questionário de Estilo Atributivo Infantil de M. Seligman (CASQ) modificado por N. A. Baturina e D. A. Tsiring, e a modificação, feita pelos autores, da Escala de Teoria Implícita de C. Dweck. O estudo da esfera cognitiva dos alunos da escola primária envolve o teste progressivo de matrizes de J. Raven, o teste de pensamento criativo de P. Torrance e a adaptação de E. E. Tunik da escala de criatividade de J. Johnson. Dentro da estrutura da experiência, dois blocos de tarefas convergentes são formados: um incluindo tarefas de transitividade não-verbal (o bloco lógico) e o outro contendo tarefas volumétricas e de pensamento espacial (o bloco espacial). É estabelecido que o sucesso dos alunos do ensino fundamental, de ambos os sexos, na resolução de tarefas convergentes está associado não apenas à atitude motivacional extrínseca, construída através da instrução verbal, mas também às características psicológicas específicas do desenvolvimento das esferas cognitiva e motivacional nas crianças. A relação entre o sucesso na resolução de tarefas convergentes e as características psicológicas do desenvolvimento cognitivo e da esfera motivacional difere para meninos e meninas em idade escolar primária, o que se manifesta mais intensamente no nível de desenvolvimento do componente não-verbal, na motivação principal e nas especificidades do desenvolvimento do estilo atribucional de explicar o sucesso e o fracasso, assim como seus componentes particulares.

PALAVRAS-CHAVE: Motivação. Gênero. Tarefas convergentes. Sucesso. Alunos.

RESUMEN: El artículo presenta los resultados de un estudio empírico de características específicas del éxito de niños y niñas en edad escolar primaria en la resolución de problemas convergentes bajo la condición de variadas actitudes motivacionales. El estudio se realizó en la escuela primaria de la Institución Educativa Presupuestaria del Estado de Moscú, el complejo educativo "Escuela No. 1561" en 2016-2018. La muestra del estudio incluye 239 estudiantes de segundo grado cuya edad promedio fue de 8.2 años. 137 de los participantes del estudio eran niños y 102 niñas, lo que constituye el $57 \%$ y el 43\% de la muestra, respectivamente. La motivación se evalúa mediante la modificación de los autores del método de N.V. Elfimova "Una escalera de motivos", una versión del Cuestionario de estilo atribucional para niños (CASQ) de M. Seligman modificado por N.A. Baturina y D.A. Tsiring y la modificación de los autores de la Escala de teoría implícita de C. Dweck. El estudio de la esfera cognitiva de los estudiantes de primaria incluye la prueba de matrices progresivas de J. Raven, la prueba de pensamiento creativo de P. Torrance y la adaptación de E.E. Tunik de la escala de creatividad de J. Johnson. En el marco del experimento se forman dos bloques de tareas convergentes: uno que incluye tareas de transitividad no verbal (el bloque lógico) y otro que contiene tareas de pensamiento volumétrico y espacial (el bloque espacial). Se establece que el éxito de los estudiantes de primaria de ambos sexos en la resolución de tareas convergentes está asociado no solo a la actitud motivacional extrínseca construida a través de la instrucción verbal sino también a las características psicológicas específicas del desarrollo de las esferas cognitiva y motivacional en los niños. La relación entre el éxito en

RPGE- Revista on line de Política e Gestão Educacional, Araraquara, v. 25, n. esp. 1, p. 673-691, mar. 2021. 
la resolución de tareas convergentes y las características psicológicas del desarrollo cognitivo y la esfera motivacional difiere para niños y niñas en edad escolar primaria que se manifiesta más intensamente en el nivel de desarrollo del componente no verbal, la motivación principal y los detalles del desarrollo del estilo atribucional de explicar el éxito y el fracaso, así como sus componentes particulares.

PALABRAS CLAVE: Motivación. Género. Tareas convergentes. Éxito. Estudiantes.

\section{Introduction}

Since the time of L.S. Vygotsky who highlighted the close connection between the "intellect" and "affect" in the structure of personality, the problem of the influence of various motivational attitudes on the effectiveness of cognitive processes in children has been repeatedly becoming a subject of theoretical analysis and special research (DRUZHININ, 2001; MARGOLIS et al., 2020; SEMENOVA, 2020; FOMINA; MOROSANOVA, 2019; SHUMAKOVA, 2019; DUCKWORTH et al., 2019; LUBART et al., 2016; SAVENKOV, 2019B). A special role in stimulating the cognitive activity of a child is traditionally attributed to their motivation (BOZHOVICH, 2001; GORDEEVA et al., 2016; LEONTIEV, 2006; MATIUSHKIN, 2017; RENZULLI, 1997; SAVENKOV, 2019A; TIKHOMIROV, 2007; DAMRONGPANIT, 2019; IRVINE, 2018; TUOMINEN et al., 2020). Multiple studies note that, at the age of primary school, children of different sexes solve educational tasks with varying degrees of success (EREMEEVA; KHRIZMAN, 1998; BAREL; TZISCHINSKY, 2018; MOÈ, 2018; RODÁN et al., 2019).

A major portion of educational tasks completed by junior schoolchildren in the process of school education (despite all attempts to reform the education system) is constituted by convergent tasks. Such tasks have a singular correct answer and are primarily focused on unidirectional, logical, sequential thinking. Despite the importance of internal motivation in a child's learning (by the content and the process of the educational activity), the majority of tasks presented at school is not personally important to a child and the need to solve them is often associated with various extrinsic motivational attitudes created by a teacher. In this regard, the study of differences in the characteristics of junior school students' success in solving convergent tasks under the condition of varying extrinsic motivational attitudes appears especially relevant. A range of aspects of this problem is examined by O.Ia. Gavrilova (2019) who studied primary school students' success in solving convergent tasks under the condition of varying extrinsic motivational attitudes. In the present study, we 
examine the set of problems of gender determination of primary school students' success in solving convergent tasks under the condition of varying extrinsic motivational attitudes.

\section{Introduction}

Since the time of L.S. Vygotsky who highlighted the close connection between the "intellect" and "affect" in the structure of personality, the problem of the influence of various motivational attitudes on the effectiveness of cognitive processes in children has been repeatedly becoming a subject of theoretical analysis and special research (DRUZHININ, 2001; MARGOLIS et al., 2020; SEMENOVA, 2020; FOMINA; MOROSANOVA, 2019; SHUMAKOVA, 2019; DUCKWORTH ET AL., 2019; LUBART et al., 2016; SAVENKOV, 2019b). A special role in stimulating the cognitive activity of a child is traditionally attributed to their motivation (BOZHOVICH, 2001; GORDEEVA et al., 2016; LEONTIEV, 2006; MATIUSHKIN, 2017; RENZULLI，1997; SAVENKOV，2019A; TIKHOMIROV，2007; DAMRONGPANIT, 2019; Irvine, 2018; Tuominen et al., 2020). Multiple studies note that, at the age of primary school, children of different sexes solve educational tasks with varying degrees of success (EREMEEVA; KHRIZMAN, 1998; BAREL; TZISCHINSKY, 2018; MOÈ, 2018; RODÁN et al., 2019).

\section{Materials and Methods}

One of the foundations of our experimental work is represented by the attributional approach to motivation formed by several individual theories. For instance, the causal attribution theory developed by B. Weiner (1986) focuses on the reasons by which a person explains their successes and failures in the study of motivation. It has a lot of commonalities with and is complemented in the key aspects by the theory of learned helplessness and attributional style proposed by an American psychologist M. Seligman (2006). His studies demonstrate that to understand motivation, it is crucial to not only identify the particular attributions of success and failure but also to see the general pattern and account for the style of these explanations. The attributional approach was developed within the framework of the sociocognitive theory developed by K. Dweck (2000) who proposed considering a person's ideas about their own abilities and the possibilities of changing them as the main factors of cognitive productivity. Among the theories of motivation, the idea of self-efficacy proposed by A. Bandura (1997) and the theory of self-determination developed in the works of E. Deci 
and R. Ryan (2008) are of particular interest from the point of our study. What also draws our interest are the studies of the correlation of motivation and cognitive processes presented by the author of the "flow theory" Chiksentmikhaii (2015). The results of theoretical and empirical studies of the motivational and need spheres of personality are also quite significant in the context of our research (GAVRILOVA, 2019; GORDEEVA et. al., 2016; DALGATOV，2006; DERGACHEVA，2005; KRIVOVA，2013; LEONTIEV，2000; CHIRKOV, 1996, etc.).

The trend of combining disparate, not always interconnected concepts of motivation present in modern psychology manifests in the development of the theory of an integrative model of educational motivation and achievement motivation implying a structural and procedural approach to its study (GORDEEVA, 2015). At present, it can be noted that with all the variety and ambiguity of interpretations of motivation and the strength of its influence on the effectiveness of the functioning of the cognitive sphere of personality by different authors, it can be concluded that these interpretations are not so much opposed to each other as they are consonant and complementary.

The results of studies on sex differences in cognitive abilities are ambiguous. For instance, the studies conducted by Colom and García-López (2002) on large samples did not demonstrate significant sex differences in intellectual characteristics. The works of other scientists state that in general, men demonstrate higher results than women in terms of intellect (MACCANN, 2010).

Special interest in the context of our study is drawn by the studies by V.N. Druzhinin (2001) and C-P. Dang and colleagues (DANG et al., 2012) noting that the spatial abilities are more pronounced in men than in women while women are more likely to lead in terms of visual search and verbal abilities (MAITLAND et al., 2000).

Based on this, we can assume that boys and girls of primary school age may differ significantly in success in solving non-verbal and volumetric and spatial convergent tasks under the condition of varying motivational attitudes. Therefore, the main hypothesis of our study is that the success of junior school children of different sexes in solving convergent tasks is associated not only with the extrinsic motivational attitude constructed through verbal instruction (GAVRILOVA, 2019) but also with the psychological characteristics of the development of children's cognitive and motivational spheres. The following specific hypotheses were also formulated and tested in the study: 
1. The relationship between the successfulness of solving a convergent task and the characteristics of general cognitive development and the motivational sphere will differ for boys and girls of primary school age;

2. The psychological characteristics of general cognitive development and the motivational sphere of children will correlate differently with the success of children of different sexes in solving convergent tasks depending on the conditions created by varying extrinsic motivational attitudes.

The study was conducted based on several elementary schools of the State Budgetary Educational Institution of Moscow "School No. 1561" educational complex. The study sample includes 239 second-grade students the average age of whom was 8.2 years old. 137 of the study participants were boys and 102 were girls which constitutes $57 \%$ and $43 \%$ of the sample, respectively.

Success in solving convergent tasks was assessed by us according to the degree of their complexity and the number of tasks solved by children. The prototypes used in the development of convergent tasks presented to children in the course of the study are presented by tasks from A.I. Savenkov's notebooks and textbooks on the development of the cognitive abilities of primary school children. We prepared two blocks of convergent tasks: non-verbal transitivity tasks (the "logical" block) and volumetric and spatial tasks (the "spatial" block). Each block included four tasks. The pilot experiment conducted before the main study allowed us to test the correspondence of the developed convergent tasks to the goals and objectives of the study. Moreover, we were able to empirically identify the degree of complexity of each task and assign points for the degree of difficulty of solving it based on this.

To get a general picture of the mental development of children participating in the study, we evaluated the levels of their general cognitive development (the intellect and creativity). The intellect was assessed using J. Raven's progressive matrices test. The level of creativity was measured through E.E. Tunik's adaptation of J. Johnson's creativity scale. Creativity was evaluated following the conclusion on the significance of the correlation between the level of development of non-verbal intelligence and creativity (DRUZHININ, 2001; KIM, 2005, etc.).

The study of motivation involved the authors' modification of N.V. Elfimova's method "A ladder of motives" allowing to identify the leading motive of the educational activity, a version of M. Seligman's Children's Attributional Style Questionnaire (CASQ) as 
modified by N.A. Baturina and D.A. Tsiring determining the dominant style of explanation of success and failure, as well as the particular components inherent in each of said types (stability of the negative, stability of the positive, generalization of the negative, generalization of the positive, personalization of the negative, personalization of the positive), and our modification of C. Dweck's Implicit Theory Scale establishing the predominant attitude towards intellect.

The statistical data processing involved the Mann-Whitney U-test and correlation analysis (Spearman's rank correlation coefficient).

Thus, the empirical study consisted of two stages:

- the first stage involved the evaluation of the general cognitive abilities (the intellect and creativity) and the characteristics of the children's personality motivational sphere development;

- the second stage involved the realization of three consecutive series of the children solving convergent tasks under the condition of varying extrinsic motivational attitudes. Each series was based on one of three external motivational attitudes ("neutral", "achieving success", and "avoiding failure"). The time interval between the series was about one month long.

The first series of the study presented the control stage. Therefore, the extrinsic motivational attitude interpreted as "neutral" was adopted as its basis. The children were asked to solve convergent tasks based on verbal instruction that the proposed set of problems will be published as a book of problems for second-grade students. However, first, we, as the authors of the problem book, have to make sure that the tasks are composed correctly and are not too easy or too difficult. The instruction designed in this manner allowed creating a situation in which the factor important to the students was the very process of solving the problem and their expert assessment of its simplicity/complexity and not the obtained results and not praise/reproval for the number of solved tasks (productivity). The lack of external impetus in the form of rewards or punishments for solving the tasks allowed us to view the results of the first series as control values for the two series following it.

The second series of the study revolved around the motivational attitude of "achieving success". The children were invited to participate in a competition in solving tasks to identify the child who is the best at solving problems at their school. In the context of this motivational attitude, increased seriousness (compared to the first series) regarding the 
process of solving the tasks was observed in the children. This finding manifested in the fact that the children looked more concentrated in the process of solving the tasks, were less distracted by extraneous matters, asked for assistance from the experimenter or their teacher, and used special instruments (rulers, erasers, etc.). Moreover, the time it took them to solve the problems increased significantly - while in the first series, the children completed the tasks in half a lesson on average (20-25 minutes), in the second series, most second-graders used the time of an entire lesson (40 minutes).

The third series of the study was based on the motivation of "avoiding failure". Through verbal instruction, an external motivational attitude consisting in that the students who do not solve the tasks will receive a negative mark (an "F") in mathematics was formed in the children. The words of the experimenter were confirmed by the teacher who was present in the classroom at the time which allowed increasing the authenticity of the experimental setting. Observation allowed us to establish that aside from the indicators of the increased importance of the situation that also appeared in the second series, the children were even more willing to use special tools (colored pencils, compasses, etc.). In addition, children were once again solving the tasks throughout the entire lesson (40 minutes) and sometimes even after its end, during the break. After the end of the lesson and the time it would have taken to "check" the results, the second graders were informed that they had completed the tasks perfectly and none of them had received a negative mark.

\section{Results}

As a result of the study, the hypothesis that primary school children of different sexes will differ in the degree of success in completing convergent tasks under the condition of varying extrinsic motivational attitudes was confirmed. In each of the three series, boys and girls of primary school age could score from 0 to 10 points. Descriptive statistics on the average points scored by the children of the two sexes as a result of solving convergent tasks under the condition of varying extrinsic motivational attitudes are presented in Table 1. 
Table 1 - Descriptive statistics of the success of the boys and girls of primary school age in solving convergent problems in the conditions of varying extrinsic motivational attitudes, in points

\begin{tabular}{|c|c|c|c|c|}
\hline Task type & $\mathrm{S}$ e $\mathrm{x}$ & $\begin{array}{c}\text { Neutral extrinsic } \\
\text { motivational } \\
\text { attitude }\end{array}$ & $\begin{array}{c}\text { Extrinsic } \\
\text { motivational } \\
\text { attitude of } \\
\text { achieving success }\end{array}$ & $\begin{array}{c}\text { Extrinsic } \\
\text { motivational } \\
\text { attitude of } \\
\text { avoiding failure }\end{array}$ \\
\hline \multirow[t]{2}{*}{ Transitivity tasks (the "logical" block) } & $\mathrm{M}$ & 5 & 4.8 & 5.1 \\
\hline & $\mathrm{F}$ & 5.2 & 4.9 & 5.2 \\
\hline \multirow{2}{*}{$\begin{array}{l}\text { Volumetric and spatial thinking tasks } \\
\text { (the "spatial" block) }\end{array}$} & $\mathrm{M}$ & 3.3 & 3.6 & 3.7 \\
\hline & $\mathrm{F}$ & 2.8 & 3.4 & 3.8 \\
\hline \multirow[t]{2}{*}{ Combined data on the two blocks } & $\mathrm{M}$ & 8.3 & 8.4 & 8.8 \\
\hline & $\mathrm{F}$ & 8 & 8.3 & 9 \\
\hline
\end{tabular}

Source: Prepared by the authors

The statistical significance of differences in the degree of success of the children of different sexes in solving convergent tasks under the condition of varying external motivational attitudes was tested using the Mann-Whitney U test. It demonstrated that at the level of the "logical" block of tasks, significant differences associated with the sex of a child solving them are lacking. Regarding the tasks of the "spatial" block, sex differences were only observed under the condition of the neutral extrinsic motivational attitude $(U=5,908, Z=-$ $2.069, \mathrm{p}=0.039)$.

To compare the results of the diagnostics of the psychological characteristics of general cognitive development (the intellect and creativity) and the motivational sphere of the personality of male and female primary school students with their success in solving convergent tasks under the condition of varying extrinsic motivational attitudes, we deployed correlation analysis (Spearman's rank correlation coefficient).

Table 2 - Correlation between the development of the cognitive and motivational personality spheres in primary school students of the two sexes and the success of solving convergent tasks under the condition of varying extrinsic motivational attitudes

\begin{tabular}{|c|c|c|c|c|c|c|c|c|c|c|}
\hline \multirow{2}{*}{} & \multirow{2}{*}{ sex } & \multicolumn{3}{|c|}{ Neutral attitude } & \multicolumn{2}{c|}{ Attitude of achieving success } & \multicolumn{2}{c|}{ Attitude of avoiding failure } \\
\cline { 2 - 11 } & & LB & SB & CD & LB & SB & CD & LB & SB & CD \\
\hline NI & M & $\mathbf{0 . 2 0 1 *}$ & $\mathbf{0 . 3 8 1 * *}$ & $\mathbf{0 . 3 5 8 * *}$ & 0.109 & $\mathbf{0 . 2 3 7 * *}$ & $\mathbf{0 . 2 4 1 * *}$ & $\mathbf{0 . 4 2 5} * *$ & $\mathbf{0 . 3 6 7 * *}$ & $\mathbf{0 . 4 7 9 * *}$ \\
\cline { 2 - 11 } & F & $\mathbf{0 . 4 1 1 * *}$ & $\mathbf{0 . 3 6 9 * *}$ & $\mathbf{0 . 4 8 0 * *}$ & $\mathbf{0 . 3 7 7 * *}$ & $\mathbf{0 . 5 6 2 * *}$ & $\mathbf{0 . 6 4 0 * *}$ & $\mathbf{0 . 5 2 3} * *$ & $\mathbf{0 . 5 2 7} * *$ & $\mathbf{0 . 6 4 8 * *}$ \\
\hline O & M & $\mathbf{0 . 2 1 9 * *}$ & 0.126 & $\mathbf{0 . 2 0 0 *}$ & -0.014 & 0.085 & 0.041 & 0.093 & 0.012 & 0.067 \\
\cline { 2 - 11 } & F & 0.059 & 0.088 & 0.100 & 0.097 & -0.064 & -0.009 & -0.097 & 0.091 & -0.032 \\
\hline C & M & $\mathbf{0 . 1 9 2 *}$ & 0.114 & $\mathbf{0 . 1 7 8 *}$ & -0.024 & 0.075 & 0.027 & 0.070 & 0.010 & 0.053 \\
\cline { 2 - 10 } & F & 0.057 & 0.120 & 0.119 & 0.107 & -0.049 & 0.005 & -0.092 & 0.098 & -0.022 \\
\hline
\end{tabular}




\begin{tabular}{|c|c|c|c|c|c|c|c|c|c|c|}
\hline \multirow[t]{2}{*}{ LM } & M & $\begin{array}{c}- \\
0.224 * *\end{array}$ & $-0.181 *$ & $\begin{array}{c}- \\
0.253 * *\end{array}$ & $-0.184 *$ & -0.024 & -0.096 & $\begin{array}{c}- \\
0.242 * *\end{array}$ & -0.120 & $\begin{array}{c}- \\
0.221 * *\end{array}$ \\
\hline & $\mathrm{F}$ & 0.172 & $0.361 * *$ & $0.379 * *$ & 0.106 & 0.091 & 0.168 & $0.240 *$ & $0.202 *$ & $0.301 * *$ \\
\hline \multirow[t]{2}{*}{$\mathrm{AS}$} & M & 0.146 & 0.120 & $0.177 *$ & 0.074 & -0.031 & 0.008 & $0.243 * *$ & 0.032 & 0.164 \\
\hline & $\mathrm{F}$ & -0.079 & 0.185 & 0.062 & 0.068 & $0.216 *$ & $0.243 * *$ & 0.196* & $0.245^{*}$ & $0.301 * *$ \\
\hline \multirow[t]{2}{*}{$\mathrm{SN}$} & M & -0.157 & 0.055 & -0.067 & -0.132 & 0.039 & -0.076 & -0.097 & 0.071 & -0.018 \\
\hline & $\mathrm{F}$ & -0.117 & -0.149 & -0.136 & -0.080 & $\begin{array}{c}- \\
0.253 * *\end{array}$ & $\begin{array}{c}- \\
0.299 * *\end{array}$ & -0.099 & $\begin{array}{c}- \\
0.262 * *\end{array}$ & $\begin{array}{c}- \\
0.234 * *\end{array}$ \\
\hline \multirow[t]{2}{*}{$\mathrm{SP}$} & M & -0.041 & 0.090 & 0.048 & -0.031 & $-0,037$ & -0.064 & -0.011 & 0.001 & -0.021 \\
\hline & $\mathrm{F}$ & -0.056 & -0.068 & -0.096 & -0.126 & 0.119 & 0.034 & -0.025 & 0.068 & 0.056 \\
\hline \multirow[t]{2}{*}{ GN } & M & $\begin{array}{c}- \\
0.300 * *\end{array}$ & $\begin{array}{c}- \\
0.215^{* *}\end{array}$ & $\begin{array}{c}- \\
0.305 * *\end{array}$ & 0.020 & $\begin{array}{c}- \\
0.243 * *\end{array}$ & -0.159 & $\begin{array}{c}- \\
0.330 * *\end{array}$ & $\begin{array}{c}- \\
0.274 * *\end{array}$ & $\begin{array}{c}- \\
0.343 * *\end{array}$ \\
\hline & $\mathrm{F}$ & -0.083 & -0.127 & -0.147 & -0.120 & -0.159 & -0.170 & -0.116 & -0.102 & -0.098 \\
\hline \multirow[t]{2}{*}{ GP } & M & $0.302 * *$ & 0.082 & $0.228 * *$ & 0.181* & -0.096 & 0.050 & $0.288 * *$ & -0.115 & 0.108 \\
\hline & $\mathrm{F}$ & $-0.253 *$ & 0.125 & -0.084 & 0.051 & -0.174 & -0.102 & -0.020 & 0.060 & 0.044 \\
\hline \multirow[t]{2}{*}{$\mathrm{PN}$} & M & 0.059 & -0.016 & 0.023 & $0.195 *$ & 0.000 & 0.158 & 0.052 & 0.017 & 0.013 \\
\hline & $\mathrm{F}$ & -0.055 & -0.114 & -0.093 & -0.125 & -0.190 & $-0.229 *$ & $-0.240 *$ & -0.099 & $-0.204 *$ \\
\hline \multirow[t]{2}{*}{$\mathrm{PP}$} & M & -0.113 & -0.019 & -0.051 & 0.091 & -0.144 & -0.045 & 0.042 & 0.023 & 0.028 \\
\hline & $\mathrm{F}$ & -0.090 & 0.178 & 0.080 & 0.011 & 0.107 & 0.132 & $0.207 *$ & $0.212 *$ & $0.314 * *$ \\
\hline \multirow[t]{2}{*}{ LA } & M & 0.003 & -0.072 & -0.033 & -0.119 & -0.106 & $-0.181 *$ & $-0.196 *$ & $-0.181 *$ & $-0.203 *$ \\
\hline & $\mathrm{F}$ & -0.160 & 0.013 & -0.056 & 0.066 & -0.013 & 0.017 & -0.131 & 0.040 & -0.045 \\
\hline
\end{tabular}

Notes: ${ }^{*} p<0.05 ; * * p<0.01$

LB - the logical block; SB - the spatial block; CD - combined data on both blocks.

$\mathrm{NI}$ - non-verbal intellect; $\mathrm{O}$ - originality of thinking; C - creativity; LM - the leading motive; AS attributional style; SN - stability of the negative; SP - stability of the positive; GN - generalization of the negative; GP - generalization of the positive; PN - personalization of the negative; PP personalization of the positive; LA - the leading attitude.

Source: Prepared by the authors

As displayed in the table, the study provides data indicating an increase in the value of the correlation coefficient of non-verbal intelligence and the success of solving convergent tasks for the combined data on both blocks compared to the correlation coefficients of nonverbal intelligence and the success of solving the tasks of the "logical" and "spatial" blocks separated from one another. It is not surprising that the assessment of non-verbal intelligence indicates the general ability of an individual to solve convergent tasks. However, the general level of development of non-verbal intellect correlates differently with the success in solving convergent tasks based on the different subject material. 
It was established that, with some exceptions, the level of development of non-verbal intellect correlates positively with the success of the children of both sexes in solving convergent tasks with all three motivational attitudes $\left(r_{s}\right.$ ranging from 0.201 to 0.480 , $\mathrm{p}<0.01)$. Therefore, it can be concluded that the higher the level of development of nonverbal intellect is, the better both boys and girls solve convergent tasks which appears quite natural. However, in boys, the correlation of non-verbal intellect and the success in solving the tasks of the "logical" block in neutral conditions becomes significant to the point of a trend $\left(\mathrm{r}_{\mathrm{s}}=0.201, \mathrm{p}=0.019\right)$. It is even more impressive that under the conditions constructed using an extrinsic motivational attitude, the correlation with nonverbal intelligence in the success of boys in solving logical tasks disappears altogether $\left(r_{s}=0.109, p=0.203\right)$.

Along with non-verbal intellect, such a parameter of general cognitive development as creativity demonstrated a correlation with success in solving convergent tasks only in male primary school students and only under the condition of the "neutral" extrinsic motivational attitude. The study demonstrates that correlation with success in solving convergent tasks does not appear in boys in the presence of the other two motivational attitudes ("achieving success" and "avoiding failure"). In girls, a correlation between creativity and success in solving convergent tasks was absent for all three of the provided extrinsic motivational attitudes ("neutral", "achieving success", and "avoiding failure").

When comparing the data on the development of the motivational sphere of the children's personality with their success in solving convergent tasks under the condition of different motivational attitudes, we also discovered several significant correlations. Here it should be noted that the higher scores correspond to social motivation and the lower ones correspond to cognitive motivation. A negative correlation indicates that the lower the scores are, the higher is the success in solving convergent tasks, therefore, it can be concluded that, in this case, success in solving convergent tasks correlates with cognitive motivation. On the contrary, a positive correlation signifies the presence of a correlation between success in solving tasks and social motivation. Thus, in the presence of the neutral extrinsic motivational attitude, the boys who had cognitive motivation for learning activities were the more successful in solving the tasks $\left(\mathrm{r}_{\mathrm{s}}\right.$ ranging from -0.253 to $-0.224, \mathrm{p}<0.01$ ) while the opposite trend was found in girls - the girls who were the best at solving convergent tasks were the ones with predominantly social motivation ( $\mathrm{r}_{\mathrm{s}}$ ranging from 0.261 to $0.279, \mathrm{p}<0.01$ ). A similar correlation was discovered in the presence of the constructed extrinsic motivational attitude of avoiding failure - success in solving convergent tasks was higher in boys with 
cognitive motivation $\left(\mathrm{r}_{\mathrm{s}}=-0.221, \mathrm{p}<0.01\right)$ and girls with social motivation $\left(\mathrm{r}_{\mathrm{s}}=0.301\right.$, $\mathrm{p}<0.01)$.

At the level of the style of explaining success and failure, sex differences were identified both in the context of attributional style in general and regarding its particular elements. Under the condition of the extrinsic motivational attitude of achieving success, girls with a more optimistic attributional style were better at solving convergent tasks $\left(\mathrm{r}_{\mathrm{s}}=0.243\right.$, $\mathrm{p}<0.01)$. Similar results were obtained in the setting of the extrinsic motivational attitude of avoiding failure: the higher was the level of optimism in girls, the more successful they were in solving convergent tasks in general $\left(\mathrm{r}_{\mathrm{s}}=0.301, \mathrm{p}<0.01\right)$. In boys, such a relationship was only found regarding the logical block of tasks $\left(\mathrm{r}_{\mathrm{s}}=0.243, \mathrm{p}<0.01\right)-$ boys with the optimistic style of explaining success and failure were more successful at solving this type of tasks.

It was revealed that girls with low stability of the negative believing that negative events are short-term and not stable over time are more successful in solving tasks in the presence of the attitude of achieving success $\left(r_{s}=-0.299, p<0.01\right.$ for combined data, $r_{s}=-$ $0.253, \mathrm{p}<0.01$ for spatial tasks) and avoiding failure $\left(\mathrm{r}_{\mathrm{s}}=-0.234, \mathrm{p}<0.01\right.$ for combined data, $\mathrm{r}_{\mathrm{s}}=-0.262, \mathrm{p}<0.01$ for spatial tasks).

Male primary school students with the higher generalization of the positive (children who explained the positive things happening to them with more generalized reasons) were more successful in solving tasks from the logical block $\left(\mathrm{r}_{\mathrm{s}}=0.302, \mathrm{p}<0.01\right)$, as well as in solving convergent tasks in general $\left(\mathrm{r}_{\mathrm{s}}=0.228, \mathrm{p}<0.01\right)$ in the presence of the neutral motivational attitude. A similar correlation with success in solving tasks of the logical block is also found under the condition of the external motivational attitude of avoiding failure $\left(\mathrm{r}_{\mathrm{s}}=\right.$ $0.288, \mathrm{p}<0.01)$

Explanation of negative events with more generalized reasons, i.e. the parameter of generalization of the negative correlates negatively with success in solving convergent tasks of all types in male primary school students under the condition of the neutral motivational attitude ( $\mathrm{r}_{\mathrm{s}}$ ranging from -0.305 to $-0.215, \mathrm{p}<0.01$ ): the less generalized reasons are used to explain negative events, the higher is the success in solving the tasks. In the case of the constructed extrinsic motivational attitude of avoiding failure, a similar correlation was found in boys only at the level of spatial tasks $\left(r_{s}=-0.243, p<0.01\right)$. Under the condition of the extrinsic motivational attitude of achieving success, it was once again discovered for all types of tasks $\left(\mathrm{r}_{\mathrm{s}}\right.$ ranging from -0.343 to $\left.-0.274, \mathrm{p}<0.01\right)$. 
In female primary school students, a correlation with a different parameter - the personalization of the positive - was identified. It was demonstrated that the girls who associated the positive events happening to them with themselves and their own efforts were generally more successful in solving convergent tasks under the condition of the extrinsic motivational attitude of avoiding failure $\left(r_{s}=0.314, p<0.01\right)$.

\section{Discussion}

As a result of the conducted study, we established several findings in need of interpretation and discussion:

1. The analysis of gender differences in the degree of success of children of primary school age in solving convergent tasks demonstrated that a direct relationship with the level of development of non-verbal intelligence in the context of each external motivational attitude is only valid only for girls. Male primary school students solving convergent tasks under the condition of the extrinsic motivation attitude of achieving success show results that lack a clear pronounced correlation with the level of development of non-verbal intellect. This is probably related to the high importance of competitiveness as the socially approved behavioral strategy most characteristic of the male gender role (KON, 2002; RADINA; NIKITINA, 2011). Concentrating on the goal of "winning the competition", male primary school students successfully solve logical tasks regardless of the level of development of their non-verbal intellect. This aspect calls for further research. It should possibly be recognized that no matter how effective external motivational attitudes are, the general level of intelligence development remains the leading factor determining the success of a child in solving convergent tasks.

2. The study demonstrated that boys with predominant cognitive motivation and girls with a predominance of social motivation for educational activities are more successful in solving convergent tasks in the presence of neutral extrinsic motivational attitudes and the extrinsic motivational attitude of avoiding failure. This finding can be associated with gender stereotypes and the fact that in the process of socialization, girls are taught to be more guided by the opinions of others meaning that a sense of the importance of someone else's opinion is cultivated in them (HAUSMANN et al., 2009; DWECK et al., 1978; 2000; MOÈ, 2018). For this reason, girls with the predominant social motivation for learning activity are better at solving convergent tasks: they solve tasks to receive adults' approval, do everything "right". 
Naturally, a similar correlation was detected under the condition of the constructed extrinsic motivational attitude of avoiding failure - the success in solving convergent tasks has higher in boys with cognitive motivation and girls with social motivation. For these girls, the desire to avoid failure in the form of a low grade and the accompanying censure from adults (teachers, parents, etc.) is much more significant which leads to increased success in solving the tasks.

Particular components of the style of attribution of success and failure (stability of the negative, personalization of the positive, generalization of the negative, etc.) also demonstrate pronounced sex differences in primary school children. We associate these results with the specific characteristics of gender socialization of children and the gender stereotypes present in society.

\section{Conclusion}

1. In the process of the empirical study, the hypothesis that the success of primary school students of different sexes in solving convergent tasks is associated not only with the extrinsic motivational attitude constructed through verbal instruction but also with the psychological characteristics of the development of the children's cognitive and motivational sphere was confirmed. Moreover:

- the hypothesis that the higher is the level of development of children's nonverbal intelligence, the more successful they are at solving convergent tasks regardless of the extrinsic motivational attitude presented to them was only true for girls;

- male primary school students demonstrate high results in solving specific types of convergent tasks under the condition of the extrinsic motivational attitude of achieving success with no correlation with the level of development of their non-verbal intelligence;

- $\quad$ under the condition of neutral extrinsic motivational attitudes and the attitudes of avoiding failure, the students most successful in solving convergent tasks are boys with the predominant cognitive motivation and girls with the predominant social motivation for the educational activity.

2. The relationship between the success in solving a convergent task and the psychological characteristics of cognitive development and the motivational sphere differs for boys and girls of primary school age which manifests most intensely in the level of development of non-verbal intelligence, the leading motivation, and the specifics of the 
development of the attributional style of explaining success and failure, as well as its particular elements.

3. The psychological characteristics of the cognitive development and the motivational sphere of children correlate differently with the success of children of different sexes in solving convergent tasks depending on the conditions created through the varying extrinsic motivational attitudes - the neutral, the attitude of achieving success, and the attitude of avoiding failure.

Our study demonstrated that primary school students' success in solving convergent tasks is affected not only by the presented extrinsic motivational attitude but also by the specific characteristics of the development of the cognitive and motivational spheres of the personality of a child solving the task. The sex of a child plays a major role: girls' success in solving convergent tasks is typically closely associated with the level of development of their cognitive sphere while in boys presented with the extrinsic motivational attitude of achieving success, the characteristics of the development of their motivational sphere take the leading role.

The psychological characteristics of children of primary school age are quite specific; therefore, the results of the study cannot be extrapolated on children of other ages and this problem most definitely calls for further empirical research. Considering the development of the cognitive and the motivational and need spheres of the personality of children of different ages, it is important to understand which extrinsic motivational attitudes correspond to the socially desirable characteristics and stimulate cognitive processes best and which extrinsic motivational attitudes and conditions in which they are presented can become effective tools improving the success of children (both boys and girls) in solving educational and other types of tasks. It is important to study how a child's gender stereotypes evolve as they grow up and how these stereotypes affect cognitive activity.

\section{REFERENCES}

BANDURA, A. Self-efficacy. The exercise of control. New York: Freeman and Co, 1997.

BAREL, E.; TZISCHINSKY, O. Age and sex differences in verbal and visuospatial abilities. Advances in Cognitive Psychology, v. 14, n. 2, p. 51-61, 2018.

BOZHOVICH, L. I. Problemy formirovaniia lichnosti: Izbrannye psikhologicheskie trudy [Problems of personality formation: Selected psychological works]. 3. ed. Moscow: Moskovskii psikhologo-sotsialnyi institute, 2001. 
CHIKSENTMIKHAII, M. Flow: the psychology of optimal experience. Moscow: Smysl, 2015.

CHIRKOV, V. I. Samodeterminatsiia i vnutrenniaia motivatsiia povedeniia cheloveka [Selfdetermination and intrinsic motivation of human behavior]. Voprosy psikhologii, n. 3, p. 116-131, 1996.

COLOM, R.; GARC A-LÓPEZ, O. Sex differences in fluid intelligence among highschool graduates. Personality and Individual differences, v. 32, n. 3, p. 445-451, 2002.

DALGATOV, M. M. Kauzalnye atributsii dostizhenii kak faktor effektivnosti uchebnoi i pedagogicheskoi deiatelnosti [Causal attribution of achievements as a factor in the effectiveness of educational and pedagogical activities]. 2006. Dissertation (Doctoral in Psychology) - Moscow State University, Moscow, 2006.

DAMRONGPANIT, S. From Modern Teaching to Mathematics Achievement: The Mediating Role of Mathematics Attitude, Achievement Motivation, and Self-Efficacy. European Journal of Educational Research, v. 8, n. 3, p. 713-727, 2019.

DANG, C. P. et al. Unitary or non-unitary nature of working memory? Evidence from its relation to general fluid and crystallized intelligence. Intelligence, v. 40, n. 5, p. 499-508, 2012.

DECI, E. L.; RYAN, R. M. Self-determination theory: a macrotheory of human motivation, development and health. Canadian Psychology, n. 49, p. 182-185, 2008.

DERGACHEVA, O. E. Lichnostnaia avtonomiia kak predmet psikhologicheskogo issledovaniia [Personal autonomy as a subject of psychological research]. 2005. Dissertation (PhD in Psychology) - Moscow State University named, Moscow, 2005.

DRUZHININ, V. N. Psikhologiia obshchikh sposobnostei [Psychology of general abilities]. Saint Petersburg: Piter, 2001.

DUCKWORTH, A. L. et al. Self-control and academic achievement. Annual Review of Psychology, n. 70, p. 373-399, 2019.

DWECK, C. S. Self-theories: their role in motivation, personality, and development. Philadelphia: Psychology Press, 2000.

DWECK, C. S. et al. Sex differences in learned helplessness: (II) The contingencies of evaluative feedback in the classroom and (III) An experimental analysis. Developmental Psychology, n. 14, p. 268-276, 1978.

EREMEEVA, V. D.; KHRIZMAN, T. P. Malchiki i devochki: dva raznykh mira. Neiropsikhologi - uchiteliam, vospitateliam, roditeliam, shkolnym psikhologam [Boys and girls - two different worlds. Neuropsychologists to teachers, educators, parents, school psychologists]. Moscow: Linka-Press, 1998.

FOMINA, T. G.; MOROSANOVA, V. I. Osobennosti vzaimosviazi osoznannoi samoreguliatsii, subektivnogo blagopoluchiia i akademicheskoi uspevaemosti u mladshikh 
shkolnikov [Specifics of relationship between conscious self-regulation, subjective wellbeing, and academic achievements of primary schoolchildren]. Eksperimentalnaia psikhologiia, v. 12, n. 3, p. 164-175, 2020.

GAVRILOVA, O. I. A. Uspeshnost resheniia konvergentnykh zadach detmi mladshego shkolnogo vozrasta $v$ usloviiakh razlichnykh vneshnikh motivatsionnykh ustanovok [Success in solving convergent tasks in children of primary school age in the face of various external motivational attitudes]. 2019. Dissertation (Ph.D. in Psychology) - Psychological Institute of the Russian Academy of Education, Moscow, 2019.

GORDEEVA T. O. Psikhologiia motivatsii dostizheniia [Psychology of achievement motivation]. Moscow: Smysl, 2015.

GORDEEVA T. O. et al. Motivatsiia samouvazheniia i uvazheniia drugimi kak faktory akademicheskikh dostizheni $\mathrm{i}$ inastoichivosti $\mathrm{v}$ uchebnoi deiatelnosti [Motivation of selfrespect and respect by others as factors in academic achievement and perseverance in educational activities]. Psikhologicheskii zhurnal, v. 37, n. 2, p. 57-68, 2016.

HAUSMANN, M. et al. Interactive Effects of Sex Hormones and Gender Stereotypes on Cognitive Sex Differences - a Psychobiosocial Approach. Psychoneuroendocrinology, v. 34, n. 3, p. 389-401, 2009.

IRVINE, J. A. Framework for comparing theories related to motivation in education. Research in Higher Education Journal, n. 35, p. 1-30, 2018.

KIM, K. H. Can only intelligent people be creative? The Journal of Secondary Gifted Education, v. XVI, n. 2/3, p. 57-66, 2005.

KON, I. S. Istoriia i teoriia muzhskikh issledovanii [History and theory of men's studies]. In: MALYSHEVA, M. M. (Ed.). Gendernyi kaleidoskop. Kurs lektsii. Moscow: Academia, 2002. p. 188-242.

KRIVOVA, V. A. Subektivnaia otsenka sobstvennykh uspekhov i neudach kak faktor kognitivnogo razvitiia mladshikh shkolnikov [Subjective evaluation of one's success and failure as a factor in cognitive development of elementary school students]. Dissertation (Ph.D. in Psychology) - Moscow state pedagogical university, Moscow, 2013.

LEONTIEV, A. N. Potrebnosti, motivy i emotsii [Needs, motives and emotions]. In: GIPPENREITER, I. B.; FALIKMAN, M.V. (Eds.). Psikhologiia motivatsi i iemotsii. 2. ed. Moscow: Omega-L, 2006. p. 57-79.

LEONTIEV, D. A. Psikhologiia svobody: k postanovke problemy samodeterminatsii lichnosti [Psychology of freedom: to the formulation of the problem of self-determination of personality]. Psikhologicheskii zhurnal, v. 21, n. 1, p. 15-25, 2000.

LUBART, T. I. et al. Introduction to the special issue "intelligence, creativity and giftedness". Learning and Individual Differences, n. 52, p. 120, 2016. 
MACCANN, C. Further examination of emotional intelligence as a standard intelligence: a latent variable analysis of fluid intelligence, crystallized intelligence, and emotional intelligence. Personality and Individual Differences, v. 49, n. 5, p. 490-496, 2010.

MAITLAND, S. B. et al. Gender differences and changes in cognitive abilities across the adult life span. Aging, Neuropsychology \& Cognition, n. 7, p. 32-53, 2000.

MARGOLIS, A. A. et al. Intellekt, kreativnost i uspeshnost resheniia zadach uchashchimisia srednegoshkolnogo vozrasta v kompiuternoi igre "PLines" [Intelligence, creativity, and performance in the "PLines" computer game in middle school age students].

Eksperimentalnaia psikhologiia, v. 13, n. 1, p. 122-137, 2020.

MATIUSHKIN, A. M. Psikhologiia myshleniia. Myshlenie kak razreshenie problemnykh situatsii: uchebnoe posobie [Psychology of thinking. Thinking as solving problem situations: a training manual]. Moscow: ID "Mezhdunarodnye otnosheniia", 2017.

MOÈ, A. Mental rotation and mathematics: gender-stereotyped beliefs and relationships in primary school children. Learning and Individual Differences, n. 61, p. 172-180, 2018.

RADINA, N. K.; NIKITINA, A. A. Sotsialnaia psikhologiia muzhestvennosti: sotsialnokonstruktivistskii podkhod [The social psychology of masculinity: a socio-constructivist approach]. Moscow: Borges, 2011.

RENZULLI, D. Z. H. Model obogashchennogo shkolnogo obucheniia [Model of enriched school education]. In: RENZULLI, D.Z.H.; RIS, S.; BOGOIAVLENSKAIA, D. B. (Eds.). Osnovnye kontseptsii odarennosti i tvorchestva. Moscow: Akademiia, 1997.

RODÁN, A. et al. Boys and girls gain in spatial, but not in mathematical ability after mental rotation training in primary education. Learning and Individual Differences, n. 70, p. 1-11, 2019.

SAVENKOV, A. Theoretical Model of Preschoolers' Social Intelligence Development. EC Psychology and Psychiatry, n. 8.3, p. 206-211, 2019a.

SAVENKOV, A. I. Psikhologiia detskoi odarennosti [The Psychology of Childhood Giftedness]: textbook. Moscow: Iurait, 2019b.

SELIGMAN, M. E. Learned optimism: how to change your mind and your life. New York: Vintage Books, 2006.

SEMENOVA, T. S. Pedagogicheskoe obshchenie uchitelia nachalnykh klassov s uchenikami kak faktor blagopoluchiia mladshikh shkolnikov v uchebnoi deiatelnosti [Pedagogical communication of a primary school teacher with students as a factor in the well-being of primary schoolchildren in educational activities]. Psikhologo-pedagogicheskie issledovaniia, v. 12 , n. 1, p. 44-58, 2020.

SHUMAKOVA, N. B. Poznavatelnaia aktivnost i kreativnost mladshikh shkolnikov s vysokimi intellektualnymi sposobnostiami v raznykh obrazovatelnykh sredakh [Cognitive activity and creativity of junior schoolchildren with high intellectual abilities in different educational environments]. Psychological-Educational Studies, v. 11, n. 1, p. 57-69, 2019. 
TIKHOMIROV, O. K. Psikhologiia myshleniia: uchebnoe posobie dlia studentov vysshikh uchebnykh zavedenii [Psychology of thinking: a textbook for students of higher educational institutions]. Moscow: Izdatelskii tsentr Akademiia, 2007.

TUOMINEN, H. et al. Motivation across a transition: Changes in achievement goal orientations and academic well-being from elementary to secondary school. Learning and Individual Differences, v. 79, 2020.

WEINER, B. An attributional theory of motivation and emotion. New York: SpringerVerlag, 1986.

\section{How to reference this article}

SAVENKOV, A.; GAVRILOVA, O. Gender characteristics of primary school students' success in solving tasks in the context of varying extrinsic motivational attitudes. Revista on line de Política e Gestão Educacional, Araraquara, v. 25, n. esp. 1, p. 673-691, mar. 2021. eISSN:1519-9029. DOI: https://doi.org/10.22633/rpge.v25iesp.1.15006

Submitted: 06/11/2020

Required revisions: $18 / 01 / 2021$

Approved: 23/02/221

Published: 01/03/2021 